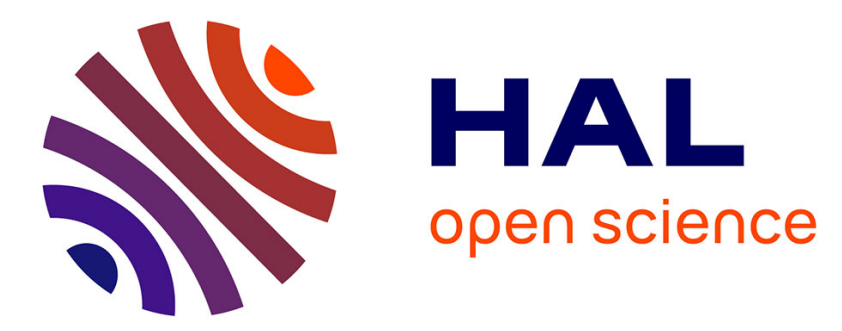

\title{
Research on evaporation of Taiyuan basin area by using remote sensing
}

\author{
X. Jin, L. Wan, Z. Su
}

\section{To cite this version:}

X. Jin, L. Wan, Z. Su. Research on evaporation of Taiyuan basin area by using remote sensing. Hydrology and Earth System Sciences Discussions, 2005, 2 (1), pp.209-227. hal-00298623

\section{HAL Id: hal-00298623 \\ https://hal.science/hal-00298623}

Submitted on 21 Jan 2005

HAL is a multi-disciplinary open access archive for the deposit and dissemination of scientific research documents, whether they are published or not. The documents may come from teaching and research institutions in France or abroad, or from public or private research centers.
L'archive ouverte pluridisciplinaire HAL, est destinée au dépôt et à la diffusion de documents scientifiques de niveau recherche, publiés ou non, émanant des établissements d'enseignement et de recherche français ou étrangers, des laboratoires publics ou privés. 
Research on evaporation of Taiyuan basin area

X. Jin et al.

\section{Research on evaporation of Taiyuan basin area by using remote sensing}

X. $\operatorname{Jin}^{1}$, L. $\mathrm{Wan}^{1}$, and Z. $\mathrm{Su}^{2}$

${ }^{1}$ School of Water Resources and Environment, China University of Geosciences, Beijing, China

${ }^{2}$ International Institute for Geo-Information Science and Earth Observation (ITC), Enschede, The Netherlands

Received: 28 December 2004 - Accepted: 13 January 2005 - Published: 21 January 2005

Correspondence to: X. Jin (jinxm @ cugb.edu.cn)

(C) 2005 Author(s). This work is licensed under a Creative Commons License.

Title Page

Abstract

Introduction

Conclusions

References

Tables

Figures

14

4

Back
Full Screen / Esc

Print Version

Interactive Discussion 


\section{Abstract}

Taiyuan basin is enclosed by hills and mountains, located in the middle of Shanxi province, standing between longitudes $111^{\circ} 40^{\prime}-113^{\circ} 00^{\prime} \mathrm{E}$ and latitude $37^{\circ} 00^{\prime}-$ $38^{\circ} 00^{\prime} \mathrm{N}$. With various types and wide distribution, the mineral resources are very abun-

5 dant in this basin area. However, there is a great shortage of water resources. Due to continual fall of groundwater level caused by excessive extraction of ground water, some severe environmental problems are induced in this area, such as ground subsidence, etc. The goal of this paper is to estimate the spatial distribution of actual evaporation over the basin by using remote sensing data.

10 The Surface Energy Balance System (SEBS) has been developed (Su, 2001, 2002). Using visible and infrared satellite remote sensing data, SEBS is based on land surface energy balance theory combined with the in-situ meteorological data or the product of atmospheric numerical model to estimate land surface turbulent flux and the relative evaporation at different scales. SEBS was served as the core methodology of this 15 paper and was used for evaporation estimation.

On the basis of hydro-geological data and NOAA satellite data, the SEBS was used in this paper for the estimation of actual evaporation of Taiyuan basin. The spatial distribution of the evaporative fraction and daily evaporation over the basin area was shown. On the other hand, the difference of land surface parameters and evaporation for various target types in the basin area was discussed.

\section{Introduction}

Evapotranspiration (ET) is a kind of very important energy in soil-vegetationatmosphere system. As a key component in water resources management, it is essential to estimate ET accurately for water resources evaluation, drought monitoring and crop production simulation. To date, there have been a series of methods for ET estimation or measurement. Most of these approaches that employ point measure-

\section{Research on evaporation of Taiyuan basin area}

X. Jin et al.

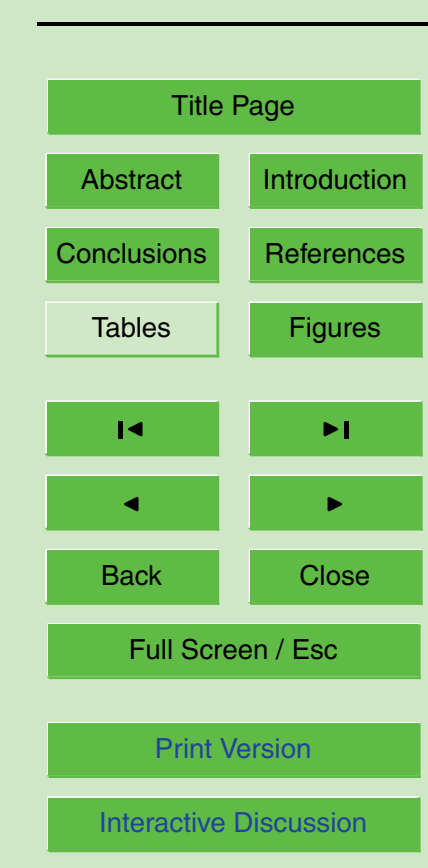

EGU 
ments to estimate ET are only representative of local scales and can not be extended to large areas because of the heterogeneity of the land surface and the dynamic nature of the heat transfer process. Therefore, conventional techniques may not be able to effectively address the prescribed complexities, resulting in large inaccuracies.

5 Remote sensing is probably one of few techniques which can provide representative measurements of several relevant physical parameters at scales from a point to a continent.

Methods using remote sensing information to estimate heat exchange between the land surface and atmosphere can be broadly put into two categories: to calculate the 10 sensible heat flux first and then to obtain the latent heat flux as the residual of the energy balance equation, or to estimate the relative evaporation by means of an index using a combination equation (Menenti, 1984; Bastiaanssen, 1995; Su and Menenti, 1999). Classical remote sensing flux algorithms based on surface temperature measurements in combination with spatially constant surface meteorological parameters 15 may be suitable for assessing the surface fluxes on a small scale, but they will fail for larger constant, the surface geometrical and thermal conditions are not homogenous and constant any more.

A Surface Energy Balance System (SEBS) for the estimation of atmosphere turbulent fluxes and surface evaporation using satellite earth observation data in the visible, near infra-red, and thermal infrared frequency range (Su, 2001) have been designed for composite terrain at a larger scale with heterogeneous surface. Being applied to some case studies in China, it has been shown that SEBS is one of the most logical and precise methods in ET estimation at present.

In this study, SEBS will be used to calculate actual ET in Taiyuan Basin, China and will provide basis for evaluation of shallow groundwater distribution in this area.

HESSD

2, 209-227, 2005

Research on evaporation of Taiyuan basin area

X. Jin et al.

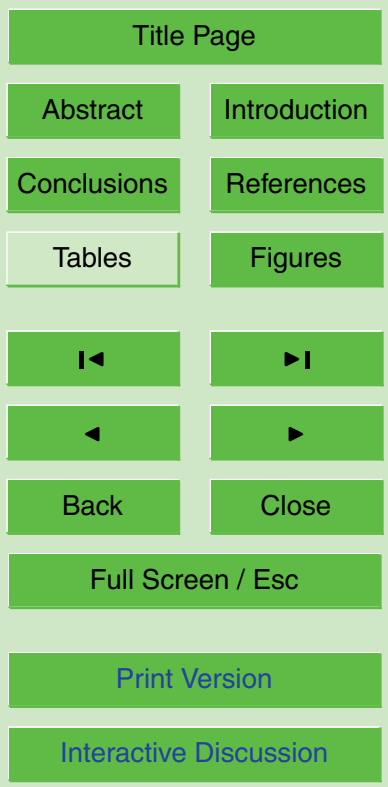

EGU 


\section{Study area}

HESSD

Taiyuan basin, surrounded by hills and mountains, is located in the middle of Shanxi province, China, with longitude/latitude between $111^{\circ} 30^{\prime}-113^{\circ} 00^{\prime} \mathrm{E}$ and $37^{\circ} 00^{\prime}-$ $38^{\circ} 20^{\prime} \mathrm{N}$. The alluvial plain lies in middle of the basin composed of large areas of 5 croplands. The strip-shaped loess mesa distributes around the basin with different width. The Fenhe River flows through all the basin area. Due to the latitude and terrain, the climate is semi-arid and the average annual precipitation is between $433 \mathrm{~mm}$ and $528 \mathrm{~mm}$.

\section{Method}

10 Using visible and infrared satellite remote sensing data, SEBS is based on land surface energy balance theory combined with the in-situ meteorological data or the product of atmospheric numerical model to estimate land surface turbulent flux and the relative evaporation at different scales.

The relative evaporation can be estimated from SEBS in following four steps: the 15 retrieval of land surface parameters; the computation of fraction wind velocity, sensible heat flux and stability length; the estimation of momentum and heat transfer roughness; the computation of relative evaporation.

The Surface Energy Balance is commonly written as

$R_{n}=G_{O}+H+\lambda E$,

20 where $R_{n}$ is the net radiation, $G_{0}$ is the soil heat flux, $H$ is the sensible heat flux, and $\lambda E$ is the latent heat flux. On the basis of energy balance and energy partitioning under dry and wet limit conditions, SEBS estimates the evaporative fraction $(E F)$ as

$E F=1-\frac{H-H_{\text {wet }}}{H_{\text {dry }}-H_{\text {wet }}}$

2, 209-227, 2005

Research on evaporation of Taiyuan basin area

$X$. Jin et al.

\section{Title Page}

Abstract Introduction

Conclusions References

Tables Figures

14

4

Back

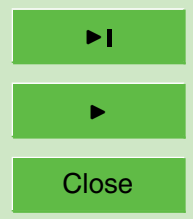

Full Screen / Esc

Print Version

Interactive Discussion 
and the daily evaporation $E_{\text {daily }}$ is expressed as

HESSD

$E_{\text {daily }}=8.64 \times 10^{7} \times \bigwedge_{0}^{24} \times \frac{R_{n}-G_{0}}{\lambda \rho_{w}}$,

2, 209-227, 2005

where $H_{\mathrm{dry}}$ is the sensible heat flux at the dry limit, $H_{\text {wet }}$ is the sensible heat flux at the 24

wet limit, $\bigwedge_{0}^{24}$ is the daily evaporative fraction, $\rho_{w}$ is the density of water.

5 Land surface parameters used in this method are albedo, NDVI and surface temperature which were derived from NOAA-AVHRR data in visible, infrared and thermal infrared spectral domain respectively. The meteorological variables were obtained by interpolating observations collected in the meteorological stations over the concerned area.

10 Evaporative fraction and daily evaporation were finally calculated by using Eqs. (2) and (3) and the data described above.

\section{Datasets}

The daily NOAA/AVHRR data in July were obtained from NOAA Satellite Active Archive (SAA) Pathfinder. The NOAA images were projected to Transverse Mercator Projection in order to be consistent with the projection of the Taiyuan Basin maps used in China.

The daily ground meteorological data were obtained from 51 meteorological stations within or around the Taiyuan Basin, including surface pressure, air temperature, dewpoint air temperature, wind speed, wind direction and surface visibility (July, 2003).

The data pre-processing includes two components: satellite remote sensing data and ground meteorological data.

4.1. Satellite data processing

Research on evaporation of Taiyuan basin area

X. Jin et al.

\section{Title Page}

Abstract Introduction

Conclusions References

Tables Figures

14

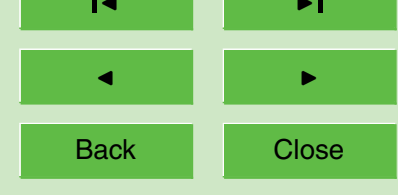

Full Screen / Esc

Print Version

Interactive Discussion

The AVHRR $1 \mathrm{~b}$ data were processed in following two steps. 
The NOAA/AVHRR $1 \mathrm{~b}$ data were converted into planetary reflectance in channel 1 and

\subsubsection{Geometry calibration}

5 The pixel geographic location, solar and satellite zenith angles can be derived from AVHRR 1b data.

\subsection{Meteorological data processing}

The meteorological data need to be interpolated and converted to match the satellite data before they are imported into SEBS.

\subsubsection{Data interpolation}

The large amount of ground measured meteorological data are required to compute the regional relative evaporation in SEBS. The ground-measured data will be interpolated into image format which are consistent with the corresponding satellite pixels in geographic coordinate. In this project, the ground measured meteorological data are interpolated with a Distance Weighing algorithm.

\subsubsection{Data conversion}

The most meteorological parameters needed in the calculation are not direct measurables, instead they are calculated or converted from the measured parameters. Therefore, the data conversion is a key pre-process. The detailed schemes are shown as

\section{Research on evaporation of Taiyuan basin area}

X. Jin et al.

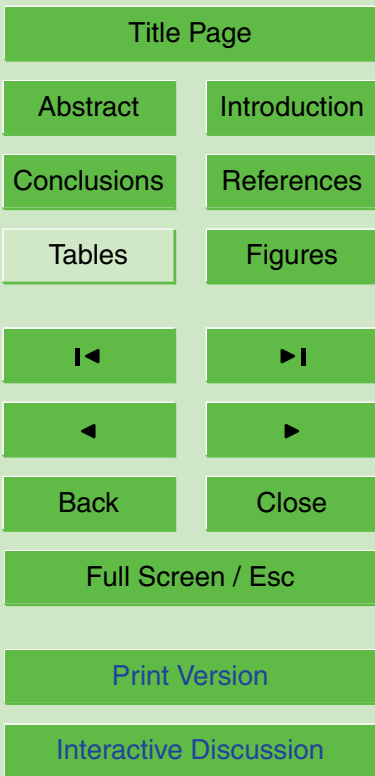

EGU 
Surface air pressure:

HESSD

$P_{s}=P_{0}\left(1-\frac{a l t}{44331}\right)^{(1 / 0.1903)} \quad(\mathrm{Pa})$,

2, 209-227, 2005

where $P_{0}$ is the sea level air pressure, alt is the altitude of observation sites.

Saturation vapor pressure:

$e_{s}=611 \exp \left(\frac{17.502 \times T_{a}}{240.97+T_{a}}\right) \quad(\mathrm{Pa})$

where $T_{a}$ is air temperature measured in near surface layer.

Actual vapor pressure:

$e=611 \exp \left(\frac{17.502 \times T d e w p t}{240.97+T d e w p t}\right) \quad(\mathrm{Pa})$

where $T d e w p t$ is the measured dew-point temperature in near surface layer.

Specific humidity:

$q=\left(R_{d} / R_{v}\right) \times e / P_{S} \quad(\mathrm{~kg} / \mathrm{kg})$,

where $R_{d}, R_{v}$ are the gas constants for the dry air and water vapor air.

Potential temperature in near surface layer:

$\theta_{a}=T_{a}\left(\frac{P_{s}}{P_{0}}\right)^{-0.286}(\mathrm{~K})$.

Back

Research on evaporation of

Taiyuan basin area

X. Jin et al.

Title Page

Abstract

Introduction

Conclusions

References

Tables

Figures

14

- I

4

Close

Full Screen / Esc

Print Version

$\theta_{v}=T_{a} \times(1+0.61 \times q) \times\left(\frac{P_{s}}{P_{0}}\right)^{-0.286}$ 
The computation consists of three parts, which are the data pre-processing, land surface parameter retrieval and the computation of relative evaporation (Lu and Su, 2002). The whole process are divided into eight steps as given in the following flowchart 5 (Fig. 1).

\section{Results and discussions}

A case study was carried out using NOAA-AVHRR data on 4 July 2003. Taiyuan basin has a large range of NDVI and surface temperature distribution with peak values around 0.2 and $40^{\circ}$. Accordingly, the evaporation over the basin shows relatively large range 10 but it apparently has two dominated categories: higher values of $E F(>0.5)$ and $E_{\text {daily }}$ $(>4.2 \mathrm{~mm})$ corresponds to the croplands area, while lower values of $E F$ and $E_{\text {daily }}$ are related to the loess area with much less vegetation covering. During the crop growth season, the higher evaporation from the croplands attributes to the irrigation. On the contrary, with relatively less precipitation, the loess area shows the natural climate characteristics of semiarid region.

\subsection{Albedo}

From the regional distribution of surface albedo (Fig. 2a) over the study area on 4 July 2003 , albedo, expressed in percentage, goes from 7.7 to 25.0 over the study area. Low values are found at city areas - Taiyuan city for instance, whiles high values are distributed at north and south mountainous area, loess mesa around the basin. Albedo ranges between 10 and 16 in the alluvial plain, the mountainous area and loess mesa around the basin has albedo of 16 to 20 .

The histogram of albedo (Fig. 2b) presents a relatively large variation of land surface reflectance, showing the complexity of land surface type. There is one peak over the

\section{Research on evaporation of Taiyuan basin area}

X. Jin et al.

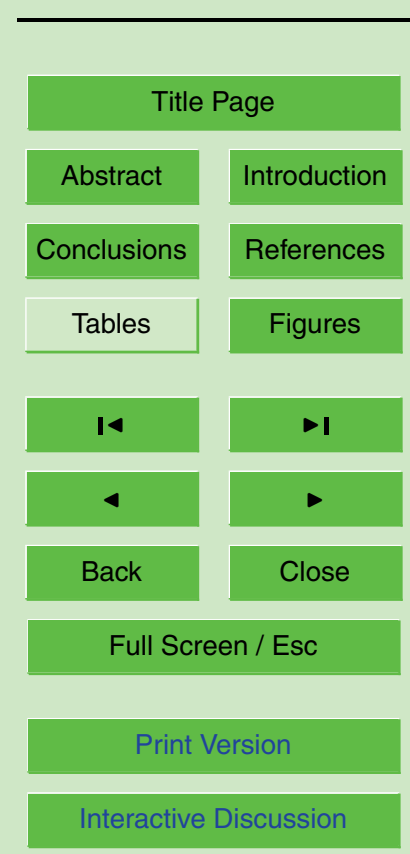

EGU 
study area, approximating to 16, concentrating in the mountainous area and loess mesa. The mean value of the surface albedo is 15.34 with a standard deviation of 5.56 .

\subsection{Emissivity}

5 The present emissivity images (Fig. 3a) are also in percent unit. It appears to be 95 to 95.5 (green) in the city areas, 95.5 to 96 in mountainous area and 96 to 96.5 in loess mesa area. High emissivity occurs at alluvial plain, with the value of 96.5 to 97 .

The histogram of land surface emissivity (Fig. 3b) presents one peak in the study area, which is around 96, occurring in the loess mesa area. The mean surface emis10 sivity is 96.45 with a standard deviation of 0.64 .

\subsection{NDVI}

The NDVI value has also been defined in percentage in this case (Fig. 4a). It should be mentioned that for the convenience of calculation, NDVI has been set to 0 for a water body although in principle it should be negative. Mountainous bare soil area and loess mesa around the basin are shown in reddish color, with value of 0 to 20, whereas in the alluvial plain, NDVI is generally between 20 and 40, locally reaching 45 .

One peak value occurs in the histogram of NDVI (Fig. 4b) over the study area, which is around $20 \% \mathrm{NDVI}$ unit, concentrating in the bare soil and loess mesa area. The mean value of NDVI is 27.14 with a standard deviation of 13.40 .

\subsection{Land surface temperature}

Land surface temperature ranges between $0^{\circ}$ and $52^{\circ}$ due to the variety of land surface type (Fig. 5a). Hot and dry bare soil is presented in reddish color, with the highest value of $52^{\circ}$. The city areas and loess mesa area around the basin show high temperatures, ranging from $40^{\circ}$ and $50^{\circ}$. The alluvial plain covered by crop land is shown in light tones of yellow, with the value of $32^{\circ}$ to $40^{\circ}$.

\section{Research on evaporation of Taiyuan basin area}

X. Jin et al.

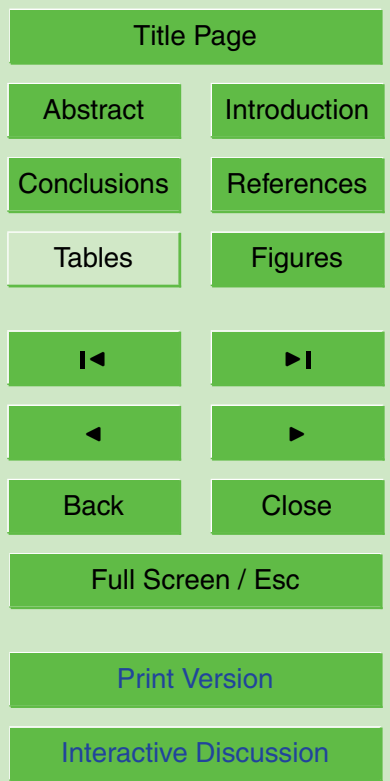

EGU 
The histogram of surface temperature (Fig. 5b) has one peak in $40^{\circ}$, which corresponded to loess mesa area. The mean value of the temperature is $39.98^{\circ}$ with a standard deviation of $5.10^{\circ}$.

\subsection{Evaporative fraction and daily evaporation}

5 The images and histograms of the calculated evaporation are shown in Fig. 6a. The evaporative fraction is confined between 0 and 1 . The highest values of 0.67 to 0.83 are shown in centre of the basin covered by crop land. Wet condition provides the potentiality for the strong evaporation. Values of 0.5 to 0.67 are found in north mountainous areas. A low evaporation fraction, ranging between 0.19 and 0.33 , is distributed in the loess area. The histogram of evaporative fraction (Fig. 6b) has two peaks in the study area, which are around 0.2 and 0.35 . The mean value is 0.43 with a standard deviation of 0.33 .

Daily evaporation (Fig. 7a) can generally match that of evaporative fraction. Low evaporation, $2 \mathrm{~mm} / \mathrm{d}$ to $3.5 \mathrm{~mm} / \mathrm{d}$, is found in the loess area around the basin. The

\section{Conclusions}

SEBS has proven to be a useful tool for evaporative estimation. This study shows that the distribution character of evaporative fraction and daily evaporation is in accordance with vegetation coverage in Taiyuan basin area. High evaporation matches higher NDVI, whereas low evaporation corresponds to bare loess soil with much less

high evaporation, varying from $4.2 \mathrm{~mm} / \mathrm{d}$ to $4.6 \mathrm{~mm} / \mathrm{d}$, is in the centre of the basin. The distribution reflects that wet conditions give more evaporation than dry conditions in spite of the high temperature in loess area. The histogram of daily evaporation (Fig. 7b) has one peak at $2.7 \mathrm{~mm} / \mathrm{d}$, the mean value of the daily evaporation is $3.2 \mathrm{~mm} / \mathrm{d}$ with a standard deviation of 1.26 .

vegetation covering.
HESSD

2, 209-227, 2005

Research on evaporation of Taiyuan basin area

X. Jin et al.

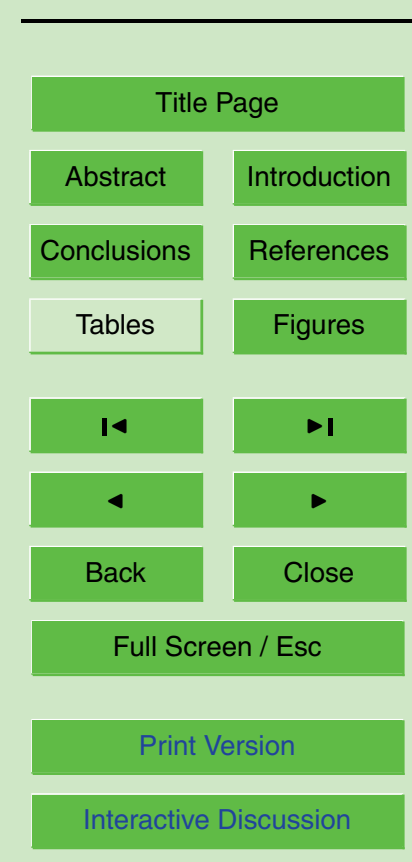

EGU 
The second conclusion is that most of the vegetation in centre of the basin area is covered by croplands and during the crop growth season, the higher evaporation from the croplands attributes to the irrigation. For the loess area, with relatively less precipitation, it shows the natural climate characteristics of semiarid region.

5 Acknowledgements. This research was supported by the Project of Evaluation of Groundwater and Environment for Shanxi Six Basins. The authors would like to express their thanks for the geological data of Shanxi Geological Institute.

We would like to thank F. Hu for discussions and suggestions and would like to acknowledge NASA for their NOAA satellite data, which were essential for the completion of this project.

\section{References}

Bastiaanssen, W. G. M. and Menenti, M.: Mapping groundwater losses in the western desert of Egypt with satellite measurements of surface reflectance and surface temperature, Water Management and Remote Sensing, J. C. Hooghat, The Hague, 61-90, 1990.

Bastiaanssen, W. G. M.: Regionalization of surface flux densities and moisture indicators in composite terrain - A remote sensing approach under clear skies in Mediterranean climates, Ph.D. thesis, Wageningen Agricultural University, The Netherlands, 273, 1995.

Chen, J., Jönsson, P., Tamura, M., Gu, Z., Matsushita, B., and Eklundh, L.: A simple method for reconstructing a high-quality NDVI time-series data set based on the Savitzky-Golay filter, Remote Sensing of Environment, 91, 332-344, 2004.

$\mathrm{Li}, \mathrm{X}$. M.: Estimation of evaporation with remotely sensed data - A case study in Urumqi river basin, Xinjiang Autonomous Region, China, M.Sc. thesis, IHE, Delft, The Netherlands, 82, 2001.

Lu, G. H., Zhang, J. J., and Su, Z.: A technique for large scale drought monitoring, Report of China National 94.8 Technique Import Project, 44, 2002.

$25 \mathrm{Ma}$, Y. M.: Estimation of evapotranspiration of Heihe area with the aid of satellite remote sensing and field observation, M.Sc. thesis, Lanzhou Institute for Plateau Atmospheric Physics, China Academy of Science, 77, 1995.

Menenti, M. and Choudhury, B. J.: Parameterization of land surface evaporation by means of 
location dependent potential evaporation and surface temperature range, Proc. Yokohama Symposium, IAHS Pbul, 212, 561-568, 1993.

HESSD

Menenti, M.: Physical aspects and determination of evaporation in deserts applying remote sensing techniques. Institute for Land and Water Management Research (ICW), The Nether5 lands, 202, 1998.

Ray, S. S. and Dadhwal, V. K.: Estimation of crop evapotranspiration of irrigation command area using remote sensing and GIS, Agricultural Water Management, 49, 239-249, 2001.

Roerink, G. J., Su, Z., and Menenti, M.: S-SEBI: A simple remote sensing algorithm to estimate the surface energy balance, Phys. Chem. Earth., 25, 147-157, 2000.

10 Shanxi Geological Survey Institute: Report on geological survey of six basins, Shanxi, China, 67, 2003.

Su, Z.: A Surface Energy Balance System (SEBS) for estimation of turbulent heat fluxes from point to continental scale, Advanced Earth Observation-Land surface Climate, Publications of the National Remote Sensing Board(BCRS), USP-2, 01-02, 183, 2001.

Su, Z., Menenti, M., Pelgrum, H., Herk, B. J. J. M., and Bastiaanseen, W. G. M.: Remote sensing of land surface fluxes for updating numerical weather predictions, In Operational Remote Sensing for Sustainable Development, edited by Nieuwenhuis, G. J. A., Vaughan, R. A., Molenaar, M., Balkema, 393-402, 1998.

Su, Z.: The Surface Energy Balance System (SEBS) for estimation of turbulent heat fluxes, Hydrol. Earth Sys. Sc., 6, 85-89, 2002, SRef-ID: 1607-7938/hess/2002-6-85.

Sun, R., Gao, X., Liu, C. M., and Li, X. W.: Evapotranspiration estimation in the Yellow River Basin, China using integrated NDVI data, Int. J. Rem. Sens., 25, 2523-2534, 2004.

Wang, J. M., Ma, Y. M., Menenti, M., Bastiaanssen, W. G. M., and Mitsuta, Y.: The scaling-up of processes in the heterogeneous landscape of HEIFE with the aid of satellite remote sensing, J. Meteorol. Soc. Jap., 73, 1235-1244, 1995.

2, 209-227, 2005

Research on evaporation of Taiyuan basin area

X. Jin et al.

\section{Title Page}

\section{Abstract} Introduction

Conclusions References

Tables Figures

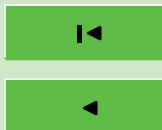

\section{$>1$}

Back

Close

Full Screen / Esc

Print Version

Interactive Discussion 


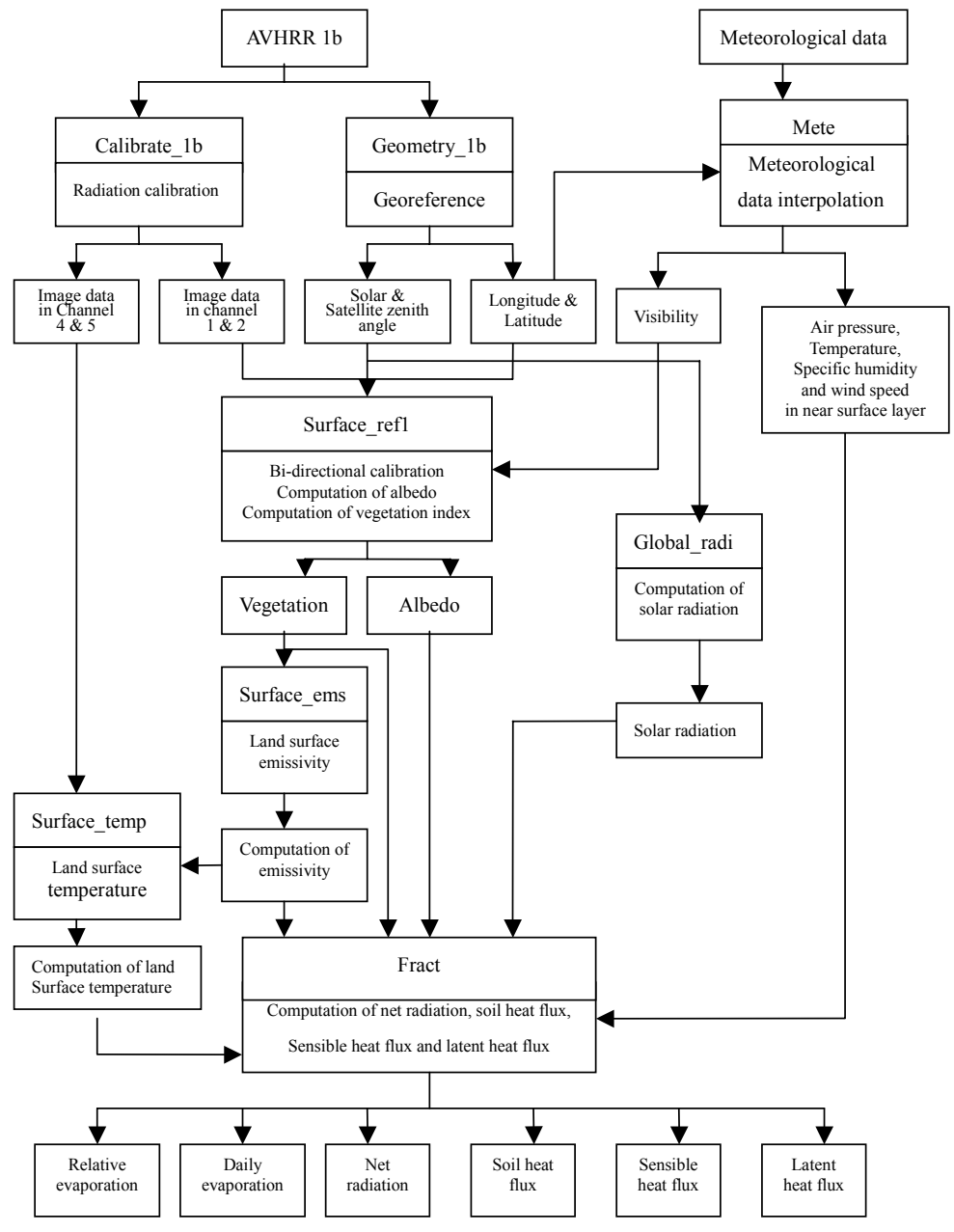

HESSD

2, 209-227, 2005

\section{Research on evaporation of Taiyuan basin area}

X. Jin et al.

\section{Title Page}

\begin{tabular}{|c|c|}
\hline Abstract & Introduction \\
\hline Conclusions & References \\
\hline Tables & Figures \\
\hline I & \\
\hline & -1 \\
\hline Back & \\
\hline
\end{tabular}

Full Screen / Esc

Print Version

Interactive Discussion

EGU 

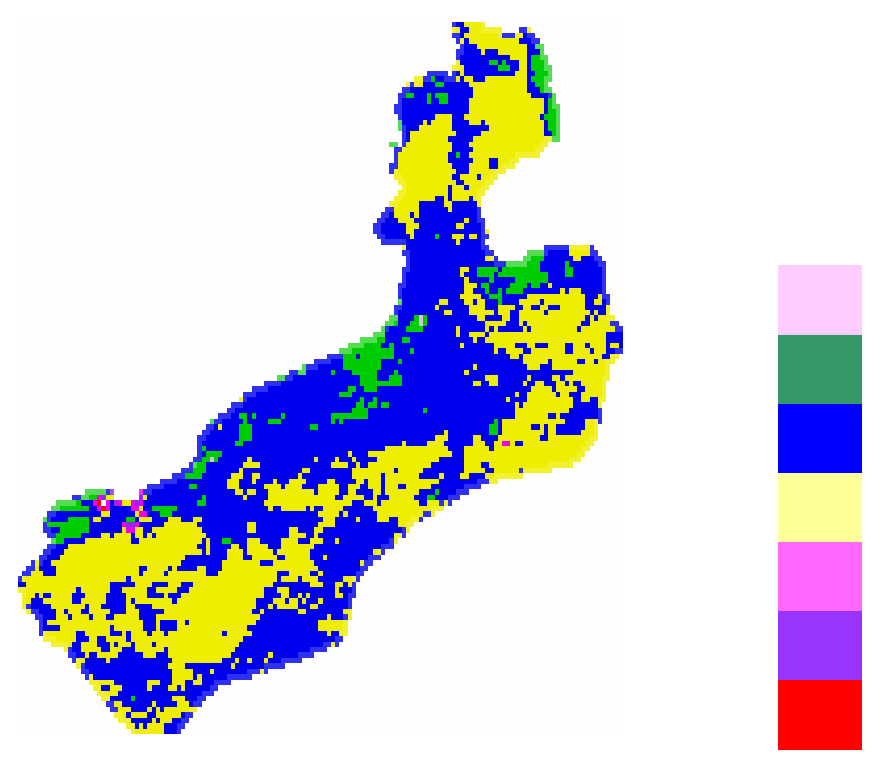

10

13

16

20

30

40

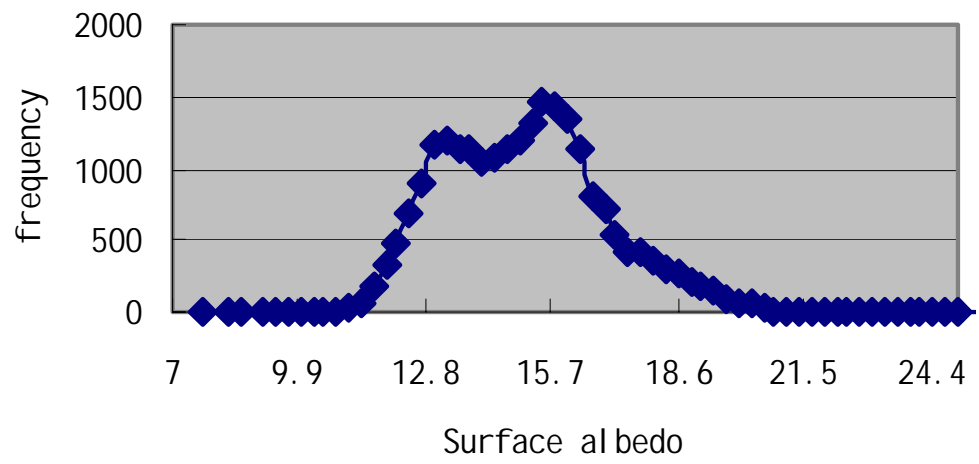

Fig. 2. (a) Image of surface albedo. (b) Histogram of surface albedo.

\section{HESSD}

2, 209-227, 2005

\section{Research on evaporation of Taiyuan basin area}

X. Jin et al.

Title Page

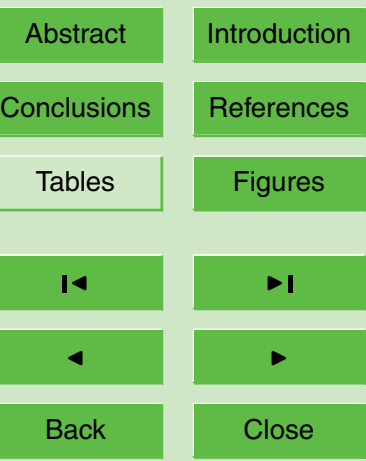

Full Screen / Esc

Print Version

Interactive Discussion 

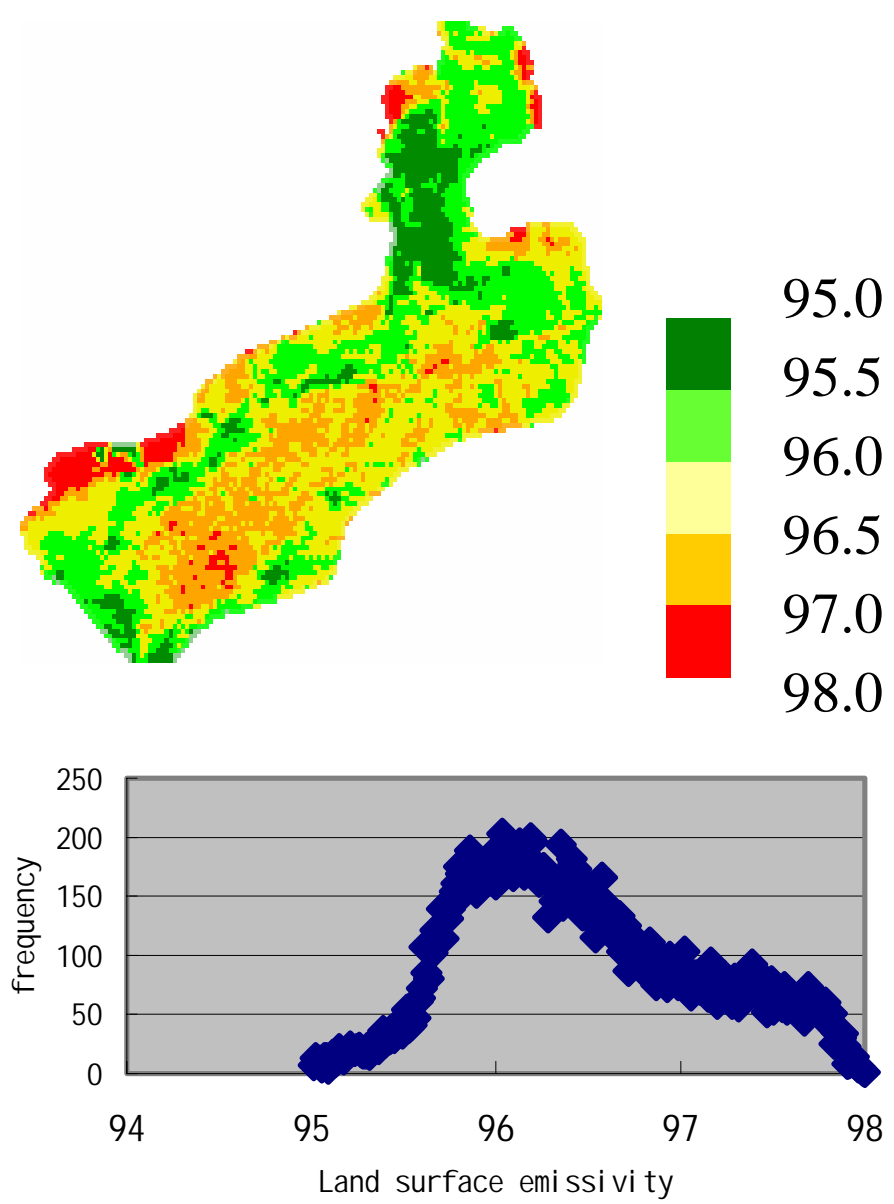

Fig. 3. (a) Image of emissivity. (b) Histogram of surface emissivity.

\section{HESSD}

2, 209-227, 2005

\section{Research on evaporation of Taiyuan basin area}

X. Jin et al.

Title Page

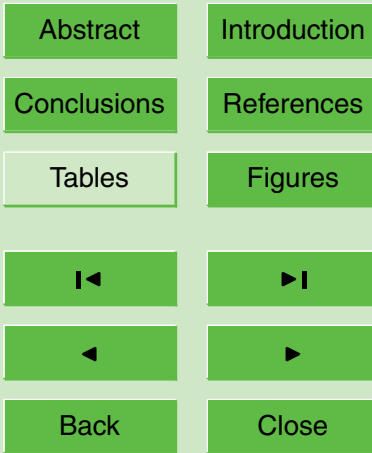

Full Screen / Esc

Print Version

Interactive Discussion 

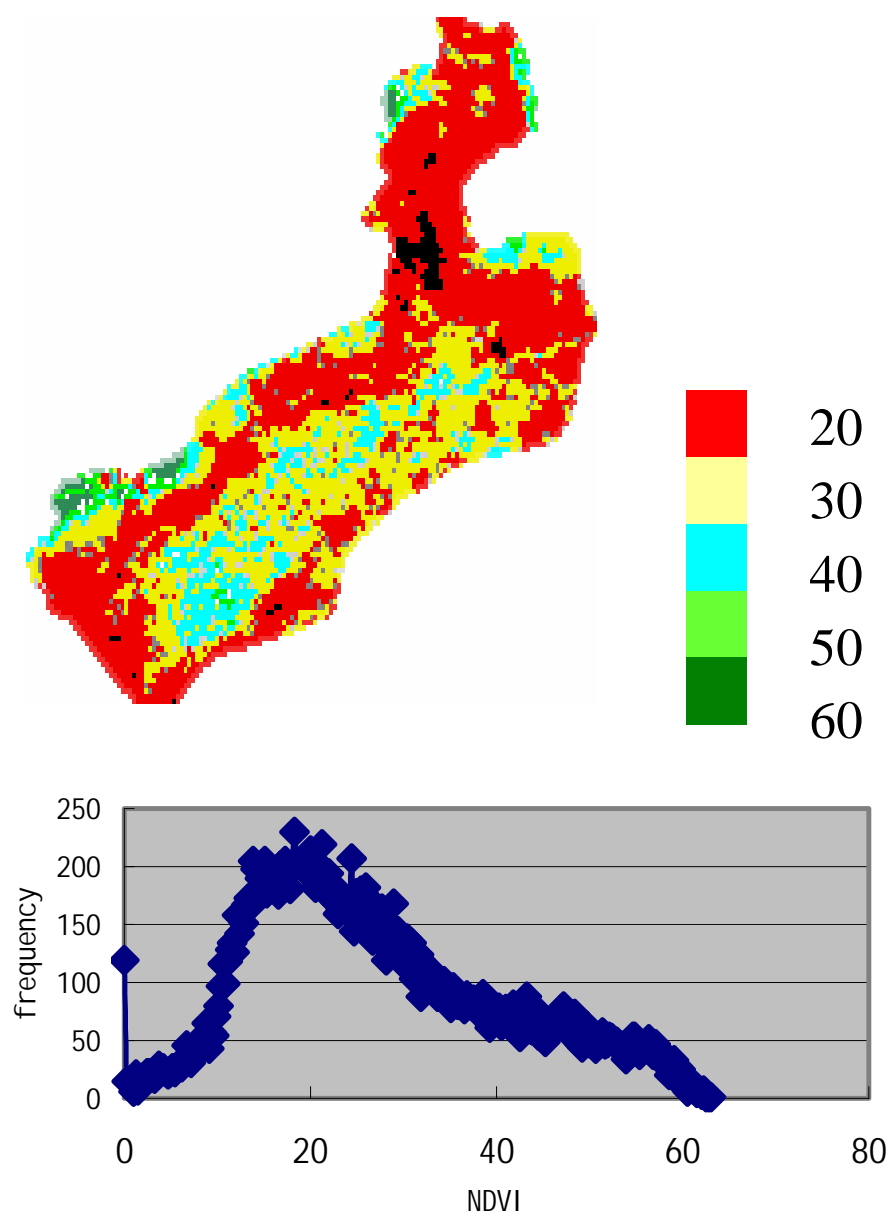

Fig. 4. (a) Image of NDVI. (b) Histogram of NDVI.

HESSD

2, 209-227, 2005

Research on evaporation of Taiyuan basin area

X. Jin et al.

Title Page

Abstract

Conclusions

Tables

14

4

Back

Full Screen / Esc

Print Version

Interactive Discussion 


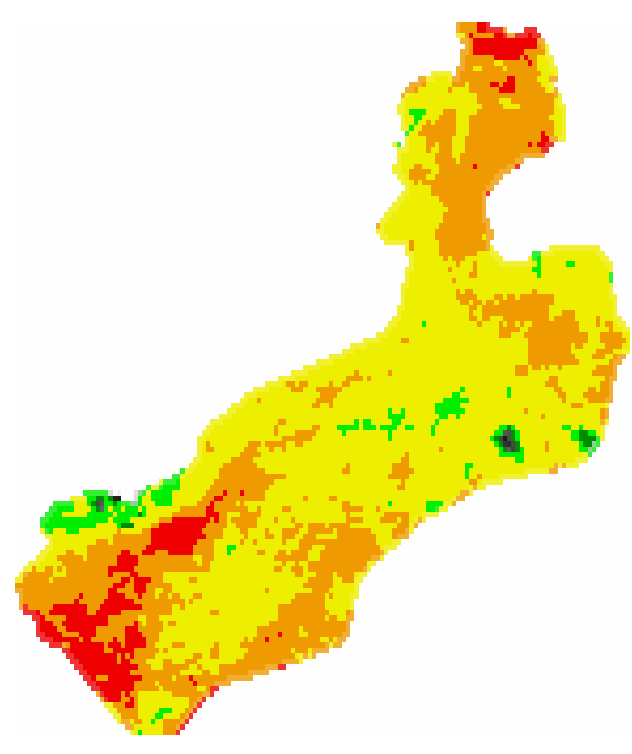

18

25

32

40

45

52

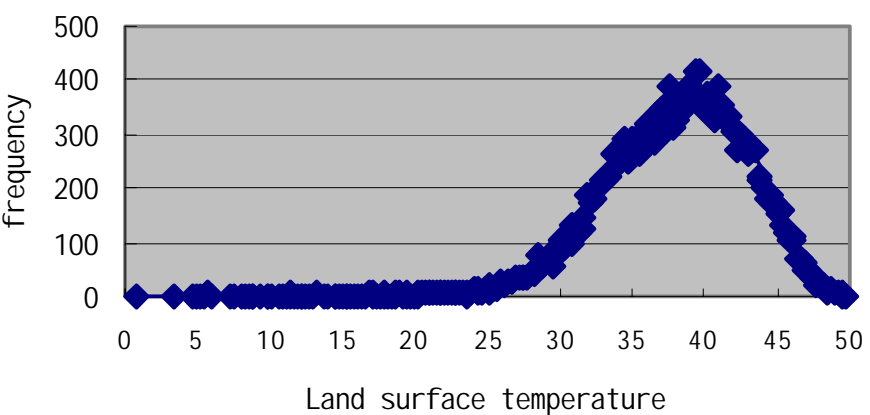

HESSD

2, 209-227, 2005

\section{Research on} evaporation of Taiyuan basin area

X. Jin et al.

Title Page

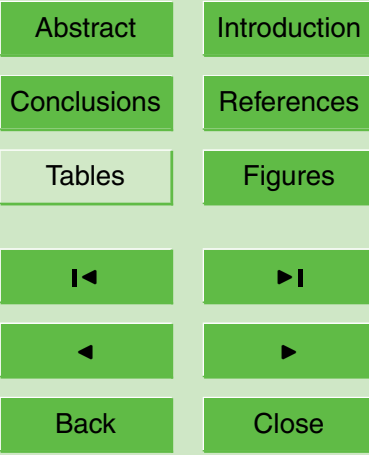

Full Screen / Esc

Print Version

Interactive Discussion

Fig. 5. (a) Image of land surface temperature. (b) Histogram of land surface temperature. 


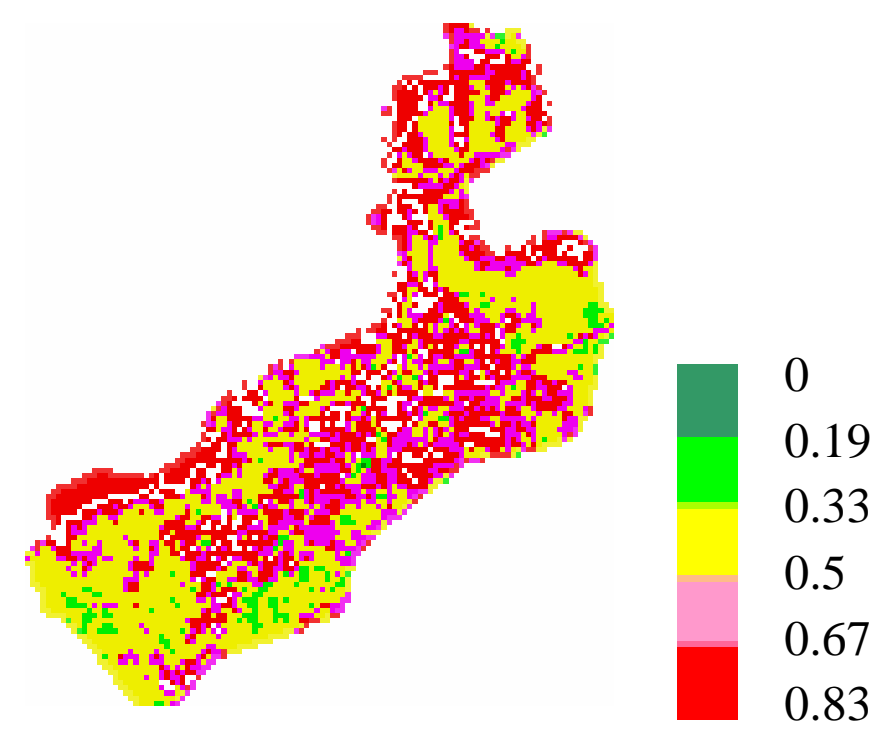

HESSD

2, 209-227, 2005

\section{Research on evaporation of Taiyuan basin area}

$X$. Jin et al.

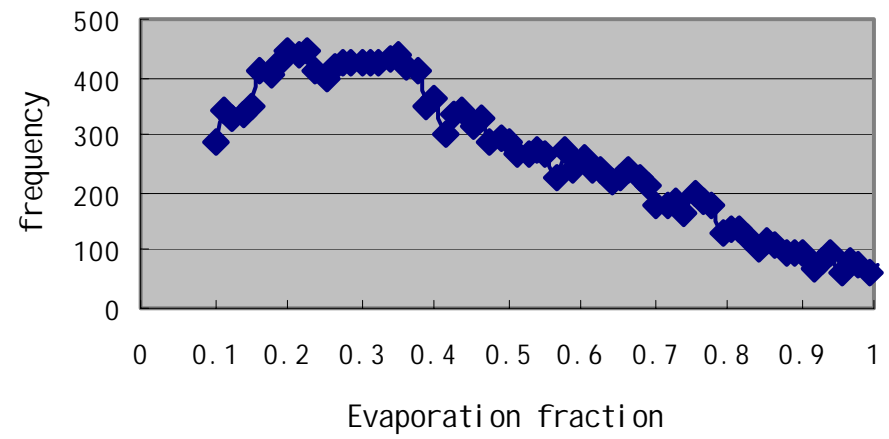

Title Page

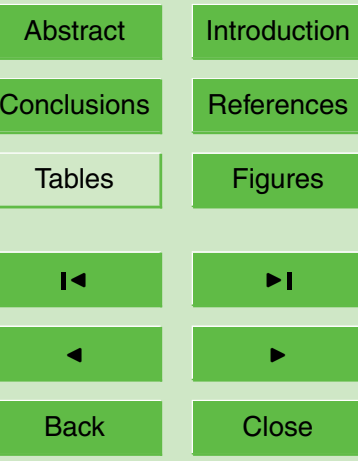

Full Screen / Esc

Print Version

Fig. 6. (a) Image of evaporative fraction. (b) Histogram of evaporative fraction. 


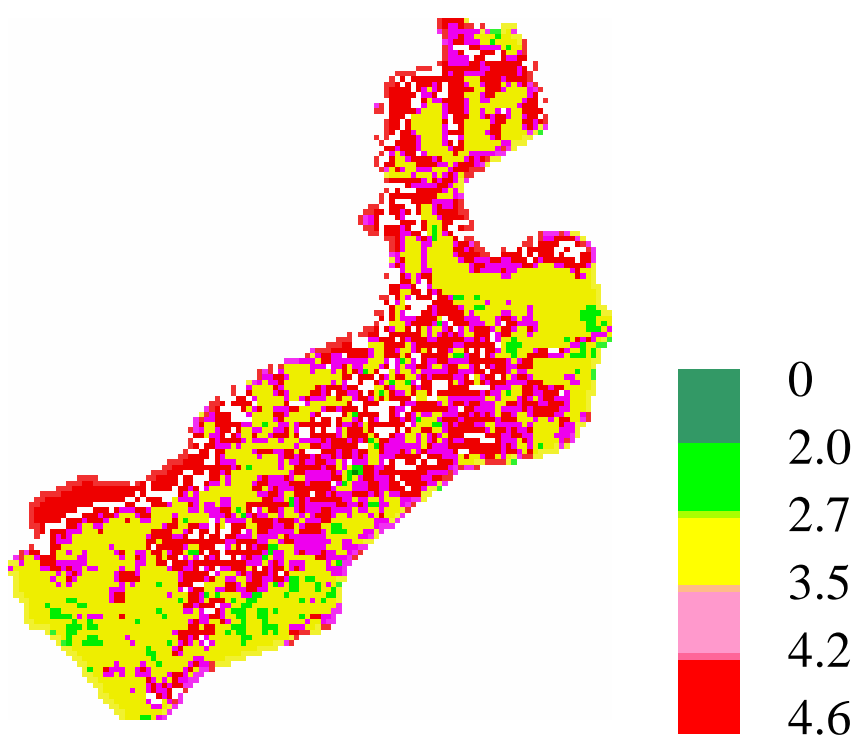

HESSD

2, 209-227, 2005

\section{Research on evaporation of Taiyuan basin area}

X. Jin et al.

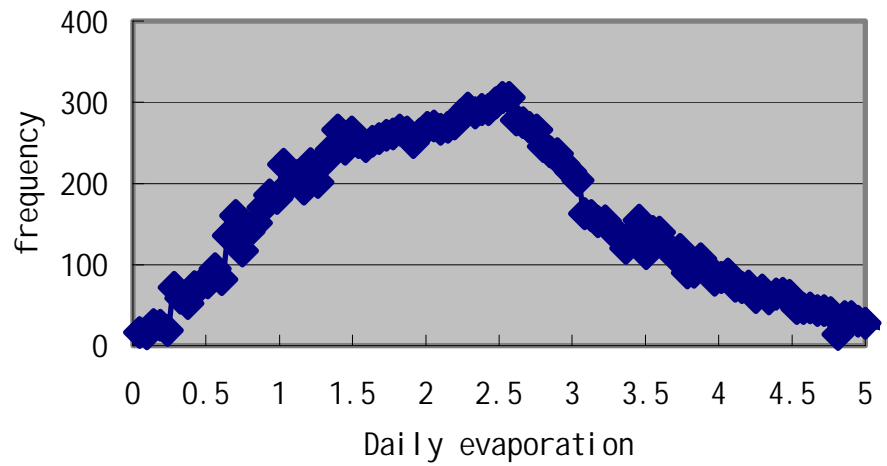

14

Title Page

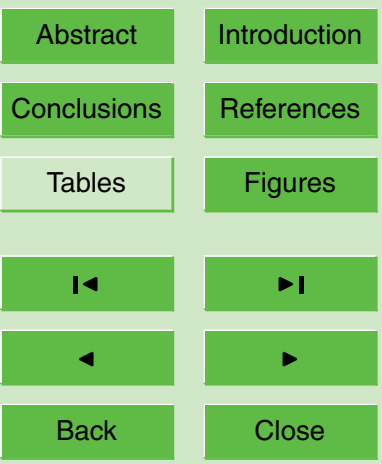

Full Screen / Esc

Print Version

Interactive Discussion

EGU 